Marquette University

e-Publications@Marquette

School of Dentistry Faculty Research and

Publications

Dentistry, School of

4-2015

\title{
Surface Modification of Biodegradable Porous Mg Bone Scaffold Using Polycaprolactone/Bioactive Glass Composite
}

\author{
Mostafa Yazdimamaghani \\ Oklahoma State University \\ Mehdi Razavi \\ Oklahoma State University \\ Daryoosh Vashaee \\ North Carolina State University \\ Lobat Tayebi \\ Marquette University, lobat.tayebi@marquette.edu
}

Follow this and additional works at: https://epublications.marquette.edu/dentistry_fac

Part of the Dentistry Commons

\section{Recommended Citation}

Yazdimamaghani, Mostafa; Razavi, Mehdi; Vashaee, Daryoosh; and Tayebi, Lobat, "Surface Modification of Biodegradable Porous Mg Bone Scaffold Using Polycaprolactone/Bioactive Glass Composite" (2015).

School of Dentistry Faculty Research and Publications. 163.

https://epublications.marquette.edu/dentistry_fac/163 


\title{
Surface Modification of Biodegradable Porous Mg Bone Scaffold Using Polycaprolactone/Bioactive Glass Composite
}

\author{
Mostafa Yazdimamaghani ${ }^{1}$ \\ School of Materials Science and Engineering, Helmerich \\ Advanced Technology Research Center, \\ Oklahoma State University, \\ Tulsa, OK \\ Mehdi Razavi ${ }^{1}$ \\ School of Materials Science and Engineering, Helmerich \\ Advanced Technology Research Center, \\ Oklahoma State University, \\ Tulsa, OK \\ Daryoosh Vashaee \\ Electrical \& Computer Engineering Department, \\ North Carolina State University, \\ Raleigh, NC \\ Lobat Tayebi \\ School of Materials Science and Engineering, Helmerich \\ Advanced Technology Research Center,
}

Materials Science and Engineering: C, Vol 49 (April 2015): pg. 436-444. DOI. This article is @ Elsevier and permission has been granted for this version to appear in e-Publications@Marquette. Elsevier does not grant permission for this article to be further copied/distributed or hosted elsewhere without the express permission from Elsevier. 
NOT THE PUBLISHED VERSION; this is the author's final, peer-reviewed manuscript. The published version may be accessed by following the link in the citation at the bottom of the page.

\author{
Oklahoma State University, \\ Tulsa, OK \\ School of Dentistry, Department of Developmental Sciences, \\ Marquette University, \\ Milwaukee, WI
}

\begin{abstract}
A reduction in the degradation rate of magnesium $(\mathrm{Mg})$ and its alloys is in high demand to enable these materials to be used in orthopedic applications. For this purpose, in this paper, a biocompatible polymeric layer reinforced with a bioactive ceramic made of polycaprolactone (PCL) and bioactive glass (BG) was applied on the surface of Mg scaffolds using dipcoating technique under low vacuum. The results indicated that the PCL-BG coated $\mathrm{Mg}$ scaffolds exhibited noticeably enhanced bioactivity compared to the uncoated scaffold. Moreover, the mechanical integrity of the Mg scaffolds was improved using the PCL-BG coating on the surface. The stable barrier property of the coatings effectively delayed the degradation activity of $\mathrm{Mg}$ scaffold substrates. Moreover, the coatings induced the formation of apatite layer on their surface after immersion in the SBF, which can enhance the biological bone in-growth and block the microcracks and pore channels in the coatings, thus prolonging their protective effect. Furthermore, it was shown that a three times increase in the concentration of PCL-BG noticeably improved the characteristics of scaffolds including their degradation resistance and mechanical stability. Since bioactivity, degradation resistance and mechanical integrity of a bone substitute are the key factors for repairing and healing fractured bones, we suggest that PCL-BG is a suitable coating material for surface modification of $\mathrm{Mg}$ scaffolds.
\end{abstract}

Keywords: Magnesium, Scaffold, Coating, Biomaterials

\title{
1. Introduction
}

Biomaterials are used in various dental and orthopedic applications such as bone substitutes, fixation and stabilization of fractured bones and total joint replacements. ${ }^{1}$ Historically, nondegradable metals, namely stainless steel, cobalt-chromium and titanium alloys, have been intensively used due to their good mechanical properties, biological performance, and degradation resistance. ${ }^{2,3}$ Currently, with the growth of tissue engineering techniques, biodegradable materials have attracted attention and their application has increased ${ }^{4}$ since they can be replaced by the host

Materials Science and Engineering: C, Vol 49 (April 2015): pg. 436-444. DOI. This article is @ Elsevier and permission has been granted for this version to appear in e-Publications@Marquette. Elsevier does not grant permission for this article to be further copied/distributed or hosted elsewhere without the express permission from Elsevier. 
tissue as well as applied for delivery of bioactive ions to improve hard tissue healing. ${ }^{5}$

Recently, magnesium ( $\mathrm{Mg}$ ) and its alloys have been presented as a new class of biodegradable metallic materials for orthopedic applications. ${ }^{1,6,7}$ By suitable surface modification, this metal can have the mechanical properties required to meet load-bearing necessities during the bone healing process ${ }^{8,9}$ and be capable of degrading at a controlled rate, thus allowing for surrounding tissue regeneration ${ }^{10,11}$ Compared to permanent metallic implants such as titanium-based materials with the Young's moduli of 110-117 GPa, the Mg-based materials have significantly lower moduli (41-45 GPa). ${ }^{12}$ As a result, the stress shielding level reduces due to their mechanical properties that are close to natural bone. ${ }^{12,13} \mathrm{Mg}$-based materials are 3-16 times stronger than biodegradable polymers; they are also more ductile, which may prevent device fracturing during the implantation process. ${ }^{1}$ Although there are concerns about the production of hydrogen by $\mathrm{Mg}$ based materials, the rate of hydrogen release can be controlled and Mg alloy implants have presented suitable in vivo biocompatibility, resulting in good host response. ${ }^{14}$ Moreover, compared to polymers, $\mathrm{Mg}$ alloys can induce bioactivity and bone growth, which can encourage the material to be well integrated with the surrounding bone as well as to potentially allow full regeneration after the degradation. ${ }^{12}$ Their appropriate properties such as elastic modulus, bioactivity, biodegradability, and biocompatibility are the main reasons for the selection of magnesium alloys as biodegradable implants. ${ }^{15,16}$

The porous microstructure of $\mathrm{Mg}$ alloys will allow for tissue ingrowth and replacement by the new bone. ${ }^{17}$ Porous scaffold constructs using various biodegradable materials for different organs have been highly popular recently due to their applications in tissue engineering. $18,19,20$

Porous Mg scaffolds may be used for bone tissue engineering uses, particularly in load-bearing applications, due to their good mechanical properties. ${ }^{21}$ Previous research on $\mathrm{Mg}$ scaffolds has been mostly focused on the mechanical properties with respect to different physical properties. ${ }^{22}$ Moreover, peri-implant bone remodeling with a good biocompatibility of $\mathrm{Mg}$ alloy scaffold has been reported. ${ }^{23}$

Materials Science and Engineering: C, Vol 49 (April 2015): pg. 436-444. DOI. This article is @ Elsevier and permission has been granted for this version to appear in e-Publications@Marquette. Elsevier does not grant permission for this article to be further copied/distributed or hosted elsewhere without the express permission from Elsevier. 
However, as a main defect, $\mathrm{Mg}$ is extremely prone to rapid degradation and corrosion in a physiological environment. ${ }^{13,24}$ If a favorable $\mathrm{Mg}$ alloy with controlled corrosion resistance is employed as a biodegradable implant, it is reasonable to assume that production of hydrogen bubbles due to the degradation is not a serious problem. ${ }^{25}$ Thus, there is a high priority to moderate the degradation rate to reach the requirements of the synchronization between the implant biodegradation and the new bone regeneration. Coating or surface modification is known as an effective approach to control the corrosion of various metallic implants. $5,26,27$

Hence, for $\mathrm{Mg}$ implants and scaffolds, novel coating can be applied to control their degradation and corrosion rate. ${ }^{28}$ Accordingly, in the present study, a polymer/ceramic composite consisting of polycaprolactone (PCL) as matrix reinforced with bioactive glass (BG) particles was employed to coat $\mathrm{Mg}$ scaffold.

$P C L$, a semi-crystalline linear resorbable aliphatic polyester, induced biodegradation due to the susceptibility to the hydrolysis. The generated products are metabolized via the tricarboxylic acid (TCA) cycle. In vitro and in vivo experiments on PCL led to its FDA approval. Presently, PCL is considered as a soft and hard-tissue compatible material including degradable suture, drug delivery vehicles, and bone graft replacements. ${ }^{29,30,31,32,33,34}$

After the discovery of bioactive glass by Hench and Wilson ${ }^{35}$ various kinds of bioactive glasses have been found to bond to the natural bone. Bioactive glasses are considered as "Class $A$ " bioactive materials which can bond to both surrounding hard and soft tissue and motivate bone growth. Formation of a surface layer made of hydroxycarbonate apatite (HCA) as a result of dissolution of calcium and silicate ions from the bioactive glass on the surface induces the bone bonding ability. $36,37,38$

To the best of our knowledge, although, the surface modification for reducing degradation rate of $\mathrm{Mg}$ bulk has been extensively studied by others, there are no reports on the polycaprolactone-bioactive glass coating on the Mg scaffolds. Thus, the main goal of this work is surface modification of $\mathrm{Mg}$ scaffold using the polycaprolactone-bioactive glass

Materials Science and Engineering: C, Vol 49 (April 2015): pg. 436-444. DOI. This article is @ Elsevier and permission has been granted for this version to appear in e-Publications@Marquette. Elsevier does not grant permission for this article to be further copied/distributed or hosted elsewhere without the express permission from Elsevier. 
NOT THE PUBLISHED VERSION; this is the author's final, peer-reviewed manuscript. The published version may be accessed by following the link in the citation at the bottom of the page.

coating to control the in vitro degradation, bioactivity and mechanical stability of this scaffold for bone tissue engineering applications.

\section{Materials and methods}

\subsection{Scaffold preparation}

Powder metallurgy technique including blending-pressingsintering method was used to produce Mg scaffolds. The initial materials were the pure magnesium powder (purity $>99 \%$, particle size $<50 \mu \mathrm{m})$ and carbonate hydrogen ammonium particles as the space-holder agent. The particle size of the spacer agent material was in the range of 150-300 $\mu \mathrm{m}$ with the volume contents of 35\%, which has been reported as the optimized value for $\mathrm{Mg}$ scaffolds to possess the mechanical properties in the range of those of natural bone. ${ }^{21}$ After blending the $\mathrm{Mg}$ powder with the space-holder agents, the mixed powders were pressed at a pressure of $400 \mathrm{MPa}$ into green compacts. They were heat treated to burn out the space holder particles and to sinter the porous samples separately in a furnace under vacuum. For the heat treatment process, the samples were heated up to $175^{\circ} \mathrm{C}$ and kept at this temperature for $2 \mathrm{~h}$, and were then heated up to $600{ }^{\circ} \mathrm{C}$ and stayed at the final temperature for $2 \mathrm{~h}$. Finally, the samples with the diameter of $6 \mathrm{~mm}$ and the length of $12 \mathrm{~mm}$ were produced.

\subsection{Coating process}

The prepared Mg scaffolds were coated with the PCL-BG layer. The PCL solution was prepared by mixing PCL $(6 \%(w / v))$ with the average molecular weight $80,000 \mathrm{~g} / \mathrm{mol}$ and dichloromethane (DCM). The $\mathrm{BG}\left(64 \% \mathrm{SiO}_{2}, 5 \% \mathrm{P}_{2} \mathrm{O}_{5}\right.$, and $31 \% \mathrm{CaO}$ (based on mol\%)), was produced by sol-gel method. ${ }^{39}$ Briefly, $14.8 \mathrm{~g}$ of tetraethylorthosilicate (TEOS) was added into nitric acid $(30 \mathrm{~mL}, 0.1 \mathrm{M})$. The mixture stirred for $0.5 \mathrm{~h}$. The following precursors were added allowing $1 \mathrm{~h}$ for each reagent to react wholly: $0.85 \mathrm{~g}$ of triethyl phosphate (TEP), and $7.75 \mathrm{~g}$ of calcium nitrate tetrahydrate $\left(\mathrm{Ca}\left(\mathrm{NO}_{3}\right)_{2} \cdot 4 \mathrm{H}_{2} \mathrm{O}\right)$. After the final addition, mixing was continued for $1 \mathrm{~h}$ to allow completion of the hydrolysis reaction. The solution was kept sealed for 10 days at $25^{\circ} \mathrm{C}$ for the hydrolysis reaction. The produced gel in a sealed beaker was

Materials Science and Engineering: C, Vol 49 (April 2015): pg. 436-444. DOI. This article is @ Elsevier and permission has been granted for this version to appear in e-Publications@Marquette. Elsevier does not grant permission for this article to be further copied/distributed or hosted elsewhere without the express permission from Elsevier. 
placed in an oven at $70{ }^{\circ} \mathrm{C}$ for 3 days. Then, the produced powders were ball milled with the rotational speed of $400 \mathrm{rpm}$ for $10 \mathrm{~h}$.

Subsequently, the milled powder was heat treated for $24 \mathrm{~h}$ at $700{ }^{\circ} \mathrm{C}$ to eliminate the nitrates.

Suspension of the PCL-BG was prepared at a total concentration of $10 \mathrm{~g} \mathrm{BG} / 100 \mathrm{~mL}$ PCL solution and treated in an ultrasonic bath for $0.5 \mathrm{~h}$. To evaluate the effect of the number of coating layers, 1 and 3 layers were applied on the Mg scaffolds. The coating process was conducted by immersing the samples in coating solution under low vacuum for $1 \mathrm{~h}$ and repressurizing those several times to make sure that the solution had been coated on the surfaces. Then, the samples were dried in room temperature under the low vacuum. The uncoated Mg scaffold, Mg scaffold with 1 layer and 3 layers of PCL-BG coating were labeled Mg scaffold, Mg scaffold/1PCL-BG and Mg scaffold/3PCL$B G$, respectively. The photographs from the produced $\mathrm{Mg}$ scaffolds according to the aforementioned procedure have been presented as insets in Fig. 1 showing the porous structure of scaffolds and the PCLBG coating on the surface in white color.
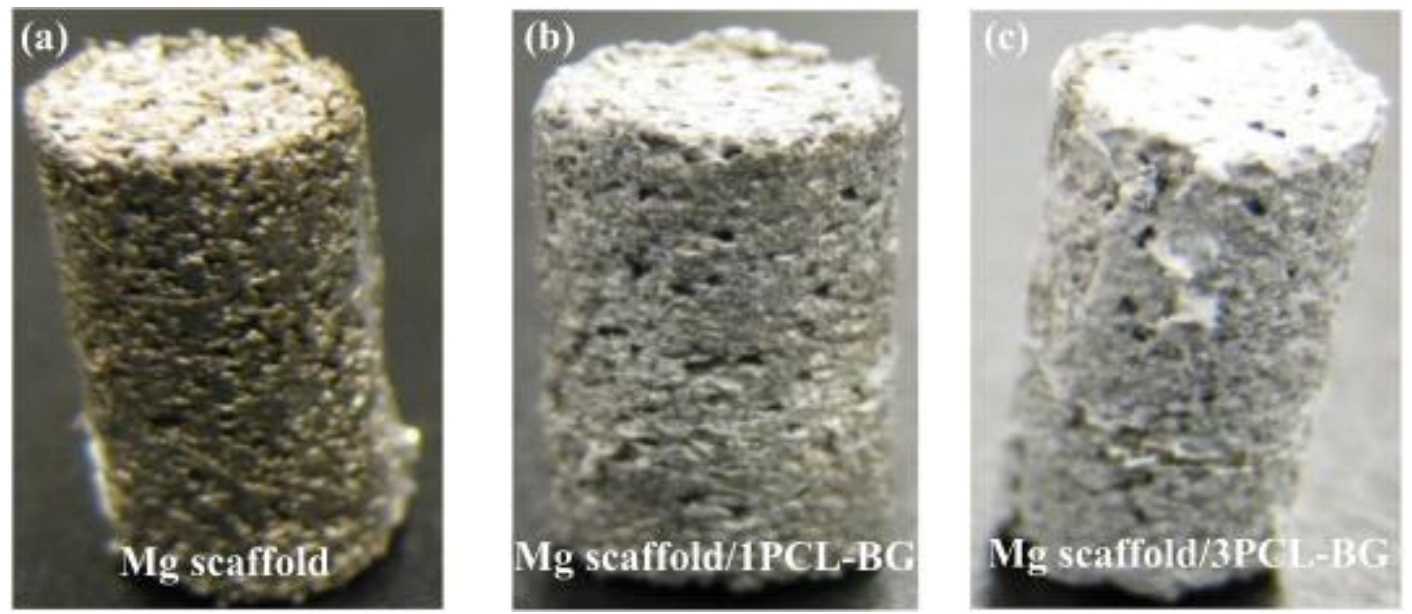

Fig. 1. Photographs of $\mathrm{Mg}$ scaffold (a), Mg scaffold/1PCL-BG (b), and Mg scaffold/3PCL-BG (c). 


\subsection{Porosity measurement}

Total porosity $(\Pi)$ of the porous samples was measured using gravimetry according to the Eq. (1):

$$
\Pi=\left(1-\rho / \rho_{s}\right) * 100 \%
$$

equation(1)

where $\rho_{s}$ is the density of the Mg scaffolds evaluated via the immersion method and $\rho$ is the apparent density of sample, which can be measured by the weight-to-volume ratio of the scaffold.

\subsection{In vitro bioactivity}

In order to evaluate the degradation, bioactivity and mechanical stability of samples during the immersion test, the samples were immersed into the simulated body fluid (SBF). The standard SBF solution was prepared according to Kokubo's protocol. ${ }^{40}$ For this purpose, initial materials including $\mathrm{NaCl}, \mathrm{NaHCO}_{3}, \mathrm{KCl}, \mathrm{K}_{2} \mathrm{HPO}_{4} \cdot 3 \mathrm{H}_{2} \mathrm{O}$, $\mathrm{MgCl}_{2} \cdot 6 \mathrm{H}_{2} \mathrm{O}, \mathrm{CaCl}_{2}$, Tris-buffer, and $1 \mathrm{~N} \mathrm{HCl}$ were used. The SBF solution was prepared by dissolving reagent-grade $\mathrm{NaCl}, \mathrm{KCl}, \mathrm{NaHCO}_{3}$, $\mathrm{MgCl}_{2} \cdot 6 \mathrm{H}_{2} \mathrm{O}, \mathrm{CaCl}_{2}$ and $\mathrm{KH}_{2} \mathrm{PO}_{4}$ into distilled water and buffering it at $\mathrm{pH}=7.25$ with Tris-buffer and $\mathrm{HCl} 1 \mathrm{~N}$ at $37^{\circ} \mathrm{C}$.

\subsection{In vitro biodegradation}

The cylindrical samples with $12 \mathrm{~mm}$ length and $6 \mathrm{~mm}$ diameter were immersed into $25 \mathrm{ml} \mathrm{SBF}$ and the immersion was carried out up to $144 \mathrm{~h}$. The changes in $\mathrm{pH}$ value of the solution were monitored by a $\mathrm{pH}$ meter (Sartorius). The amount of weight gain was calculated using the difference in weight of samples before and after immersion in the $\mathrm{SBF}$, and the difference in weight before and after chromic acid immersion for cleaning the corrosion products indicated the amount of weight loss.

\subsection{Mechanical stability}

To specify the mechanical stability of samples during the immersing, the compression test was conducted based on the standard

Materials Science and Engineering: C, Vol 49 (April 2015): pg. 436-444. DOI. This article is @ Elsevier and permission has been granted for this version to appear in e-Publications@Marquette. Elsevier does not grant permission for this article to be further copied/distributed or hosted elsewhere without the express permission from Elsevier. 
ASTM E9. The compression tests were carried out with a Shimadzu AGSX testing machine at room temperature at a rate of $1 \mathrm{~mm} / \mathrm{min}$. The compressive strength of the samples was determined using the compression test. ${ }^{41}$

\subsection{Structural characterization}

The morphology of the coating before and after the immersion test was observed using scanning electron microscopy (SEM: Hitachi UHR FE S-4800). The chemical composition of the coating was determined using energy dispersive spectroscopy (EDS: Hitachi UHR FE S-4800).

Laser scanning microscope (Keyence, VK100) was used in order to observe the topography of the scaffolds using three dimensional images. The VK analyzer was used to analyze the obtained data from the microscope.

Fourier transform infrared spectroscopy (FTIR, Agilent 680 IR) was used to identify the functional group of products formed on the surface during the immersion test.

Three samples were employed for each experiment and the mean values of experimental results were calculated. The data was stated as mean \pm standard deviation. Statistical analysis was conducted to evaluate the differences by the analysis of variance (ANOVA). The statistical significance (asterisks on the columns) was defined as $p<0.05$ indicating that the attained results from each group is noticeably different from others.

\section{Results and discussion}

\subsection{Structural characterization}

Fig. 1 shows the photographs of Mg scaffold (a), Mg scaffold/1PCL-BG (b), and Mg scaffold/3PCL-BG (c) indicating the porous structure of the produced scaffolds. The bright layer observed on the coated Mg scaffolds is due to the presence of PCL-BG coating layer on the surface of Mg scaffold/1PCL-BG and Mg scaffold/3PCL-BG.

Materials Science and Engineering: C, Vol 49 (April 2015): pg. 436-444. DOI. This article is (C) Elsevier and permission has been granted for this version to appear in e-Publications@Marquette. Elsevier does not grant permission for this article to be further copied/distributed or hosted elsewhere without the express permission from Elsevier. 
Fig. 2 shows the SEM micrographs of Mg scaffold (a), Mg scaffold/1PCL-BG (b), Mg scaffold/3PCL-BG (c), SEM micrographs and EDS analysis of cross-sectional view of Mg scaffold/3PCL-BG (d), laser scanning microscopy images of Mg scaffold (e) and Mg scaffold/3PCLBG (f), and roughness profilometry analysis of $\mathrm{Mg}$ scaffold $(\mathrm{g})$ and $\mathrm{Mg}$ scaffold/3PCL-BG (h). It can be observed in SEM images that the $\mathrm{Mg}$ scaffolds have open-cell structures (Fig. 2a). An additional layer reinforced with the particles can be seen on the surface of $\mathrm{Mg}$ substrate (Fig. 2b). The 3PCL-BG coating layer (Fig. 2c) is thicker than 1PCL-BG coating layer (Fig. 2b). According to Fig. 2d, three phases corresponding to the $\mathrm{Mg}$ scaffold substrate, the particles in the coating layer and the coating layer can be observed in the cross-sectional view of $\mathrm{Mg}$ scaffold/3PCL-BG. To identify the abovementioned phases, EDS analysis was performed which is presented as an inset in Fig. $2 d$. The existence of sharp peaks relating to $\mathrm{C}$ and $\mathrm{O}$ elements confirms the $\mathrm{PCL}$ coating and the observed $\mathrm{Si}, \mathrm{Ca}$, and $\mathrm{P}$ elements confirm the presence of BG particles. Based on the laser scanning images in Fig. $2 \mathrm{e}, \mathrm{f}$, the porosities can be observed in blue color and the usual surface of scaffolds is in red color. The length and depth of porosities are about 300, 650 and 300, $250 \mu \mathrm{m}$, respectively as can be extracted from the profilometry analysis in Fig. $2 \mathrm{~g}$, h. The porosity volume fractions of the produced scaffolds were calculated using Eq. (1), and they were measured in the range of $35-40 \%$. The volume fraction of the used space-holder agents was 35\%. Thus, the extra-pores (0-5\%) obtained from Eq. (1) may be due to the existence of the boundaries between the particles.

Materials Science and Engineering: C, Vol 49 (April 2015): pg. 436-444. DOI. This article is (C) Elsevier and permission has been granted for this version to appear in e-Publications@Marquette. Elsevier does not grant permission for this article to be further copied/distributed or hosted elsewhere without the express permission from Elsevier. 

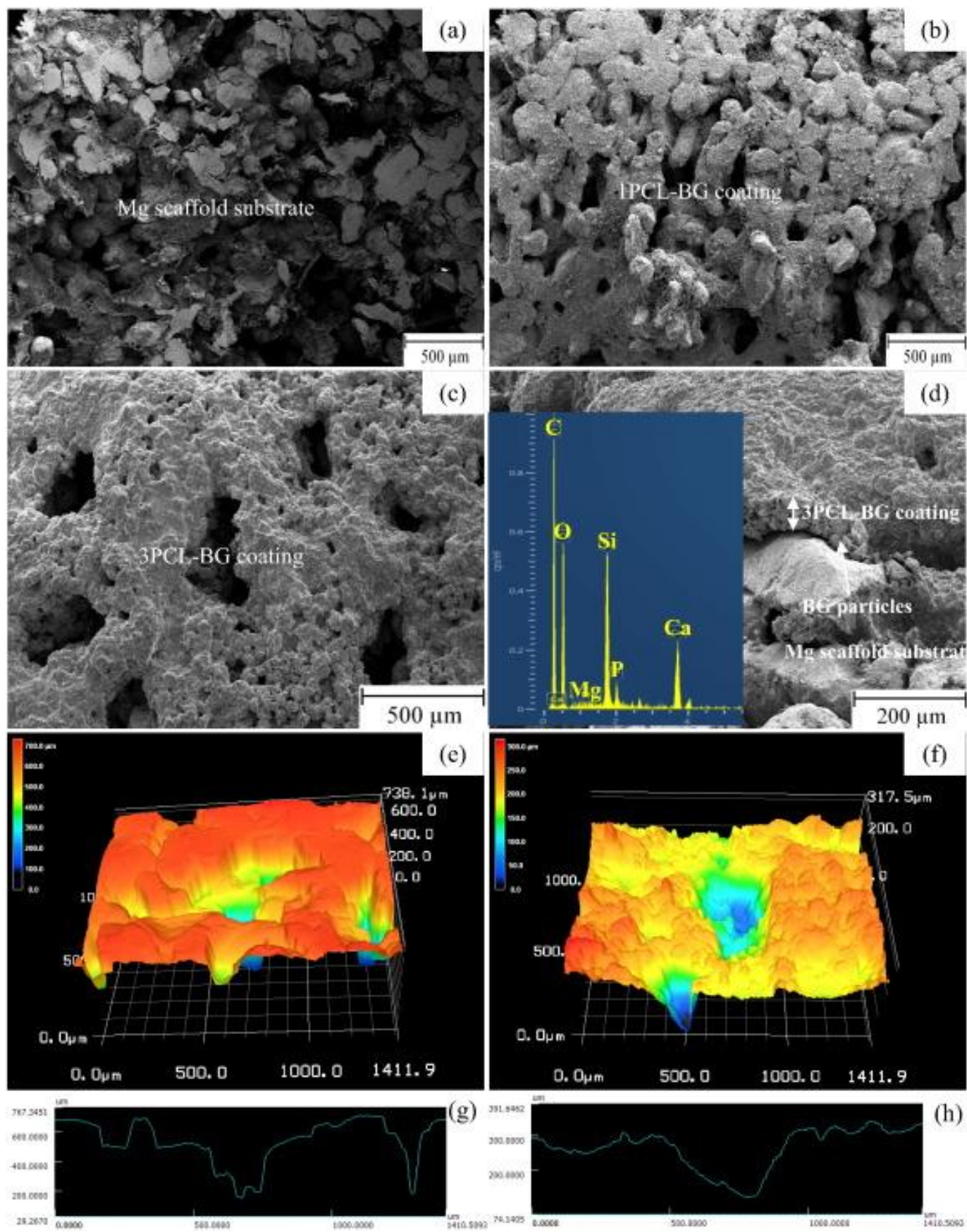

Fig. 2. SEM micrographs of Mg scaffold (a), Mg scaffold/1PCL-BG (b), Mg scaffold/3PCL-BG (c), SEM micrographs and EDS analysis of cross-sectional view of Mg scaffold/3PCL-BG (d), laser scanning microscopy images of Mg scaffold (e) and Mg scaffold/3PCL-BG ( $f$ ), and roughness profilometry analysis of $\mathrm{Mg}$ scaffold $(\mathrm{g})$ and $\mathrm{Mg}$ scaffold/3PCL-BG (h).

Fig. 3 presents the cross-sectional view of Mg scaffold/3PCL-BG. According to this Fig., the thickness of 3PCL-BG coating on the surface

Materials Science and Engineering: C, Vol 49 (April 2015): pg. 436-444. DOI. This article is (C) Elsevier and permission has been granted for this version to appear in e-Publications@Marquette. Elsevier does not grant permission for this article to be further copied/distributed or hosted elsewhere without the express permission from Elsevier. 
of $\mathrm{Mg}$ scaffolds is approximately $60 \mu \mathrm{m}$. Increasing the coating layers enlarged the coating thickness leading to a lower bonding strength of the coating to the substrate, which can cause coating delamination. Moreover, applying more layers of coating fill the surface porosities of Mg scaffold substrate, which is not favorable in tissue engineering techniques. Thus, we did not study the influence of more than 3 coating layers. On the other hand, according to our visual inspections during the coating process, we realized that the differences between 1 and 2 coating layers were not significant, and distinguishing between the characteristics of these two was difficult. Consequently, the most optimized and meaningful scenario which was a detailed comparison between PCL-BG coating with 1 and 3 layers was chosen to be investigated in this study.
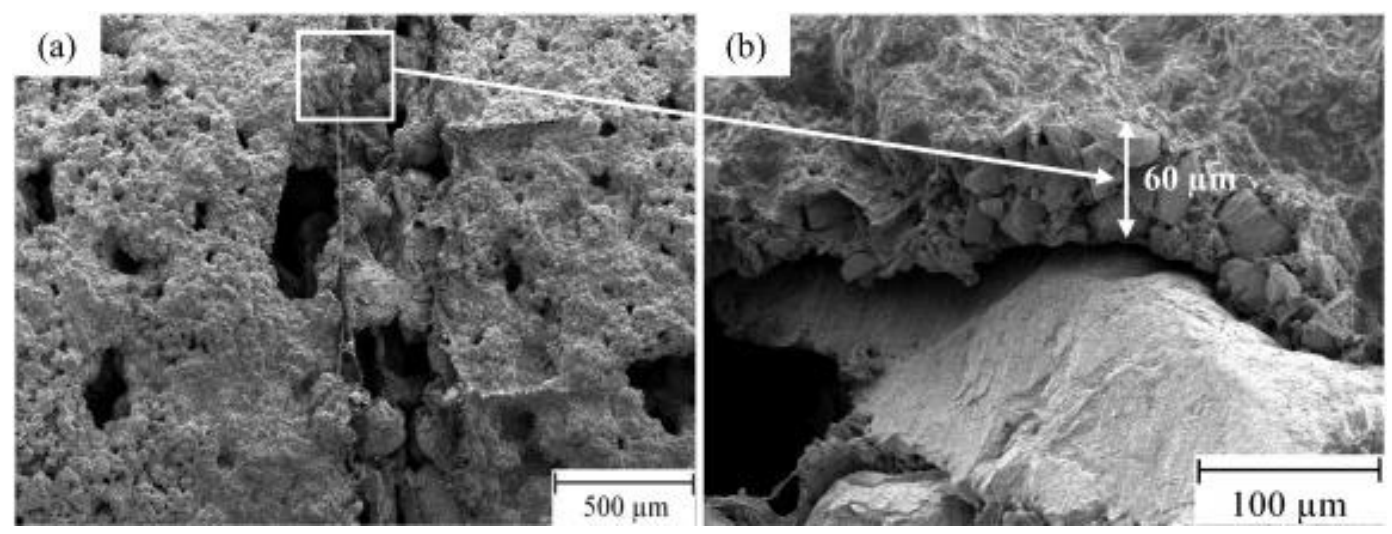

Fig. 3. Cross-sectional view of Mg scaffold/3PCL-BG in low (a) and high (b) magnifications.

\subsection{In vitro bioactivity}

Nowadays, immersion tests in the SBF are usually performed to estimate the in vitro biodegradability and bioactivity of metallic implants, providing further information with respect to the long-term degradation behavior of the coating system, including degradation rate, $\mathrm{pH}$ variation and surface morphologies. Therefore, SBF immersion tests were carried out.

The degradation behavior and in vitro bioactivity of samples versus immersion time were evaluated by immersion test in the SBF. 
Fig. 4 shows the SEM micrographs and photographs of uncoated Mg scaffold (a, b), Mg scaffold/1PCL-BG (c, d), and Mg scaffold/3PCLBG $(e, f)$ samples after $48 \mathrm{~h}$ immersion in the SBF, and FTIR spectrum of the precipitated white layers in cauliflower-like structure on the surface of samples after $48 \mathrm{~h}$ immersion in the SBF ( $g$ ) show the degradation and in vitro bioactivity behavior of samples. As shown in Fig. 4a, the uncoated Mg scaffold has been degraded severely. In addition, a white layer was found deposited on the surface as degradation products. The mentioned precipitations appear in cauliflower-like structure (Fig. 4b). From Fig. 4c, it can be observed that the Mg scaffold/1PCL-BG surface morphology has been degraded and a few cracks and pits appeared. The SEM micrographs further identify that the surfaces of Mg scaffold/1PCL-BG and Mg scaffold/3PCL-BG have been covered with the precipitates in cauliflower-like structure according to Fig. 4d, f. Regarding the comparison of the degradation and the amount of deposited layer between the Mg scaffold, Mg scaffold/1PCL-BG and Mg scaffold/3PCLBG samples, we realized that the degradation attack of the $\mathrm{Mg}$ scaffold/1PCL-BG and Mg scaffold/3PCL-BG samples was milder than that of the $\mathrm{Mg}$ scaffold indicating the degradation rate for $\mathrm{Mg}$ scaffold was reduced by PCL-BG coating. Since this layer can act as a protective layer, it may prevent the corrosive ions from reaching the substrate. Moreover, the degradation resistance can be improved by increasing the coating layers. On the other hand, the $\mathrm{Mg}$ scaffold/3PCL-BG had better degradation resistance compared to $\mathrm{Mg}$ scaffold/1PCL-BG according to the results. Moreover, the deposited white layers on the surface of Mg scaffold/3PCL-BG sample were denser than that of the Mg scaffold/1PCL-BG and Mg scaffold. It can be concluded that the deposited layer on the surface of coated samples had more time to nucleate and grow during the immersion. SBF is a supersaturated calcium phosphate solution and its chemical stimulus may activate the nucleation of bioactive minerals including phosphate and carbonate groups. The induction of bioactivity can be carried out by negatively charged groups. In particular, the formation of silanol ($\mathrm{Si}-\mathrm{OH}$ ) on the surface of BG particles is known to be beneficial for nucleation of bioactive products. These negatively charged groups attract $\mathrm{Ca}^{2}+$ which in turn makes the positively charged sites for absorbing $\mathrm{PO}_{4}{ }^{3-}$, and $\mathrm{CO}_{3}{ }^{2}$ - in the SBF. This process may eventually lead to the formation of a phosphate layer on the surface. ${ }^{42}$ Moreover,

Materials Science and Engineering: C, Vol 49 (April 2015): pg. 436-444. DOI. This article is @ Elsevier and permission has been granted for this version to appear in e-Publications@Marquette. Elsevier does not grant permission for this article to be further copied/distributed or hosted elsewhere without the express permission from Elsevier. 
by immersing the $\mathrm{Mg}$ in a physiological environment, a $\mathrm{Mg}(\mathrm{OH})_{2}$ layer forms on the surface (reaction 1 ). According to Fig. $4 \mathrm{~g}$, appearance of the $\mathrm{PO}_{4}{ }^{3-}$ (phosphate) and $\mathrm{CO}_{3}{ }^{2}$ - (carbonate) peaks in precipitates as well as observation of their cauliflower-like structure represent the formation of calcium phosphate on the surface of immersed samples, which can be beneficial for enhancing the chances of osseointegrated interface formation after implantation. ${ }^{43,44}$ Note that the attendance of $\mathrm{OH}^{-}$can represent the existence of $\mathrm{Mg}(\mathrm{OH})_{2}$ on the surface.
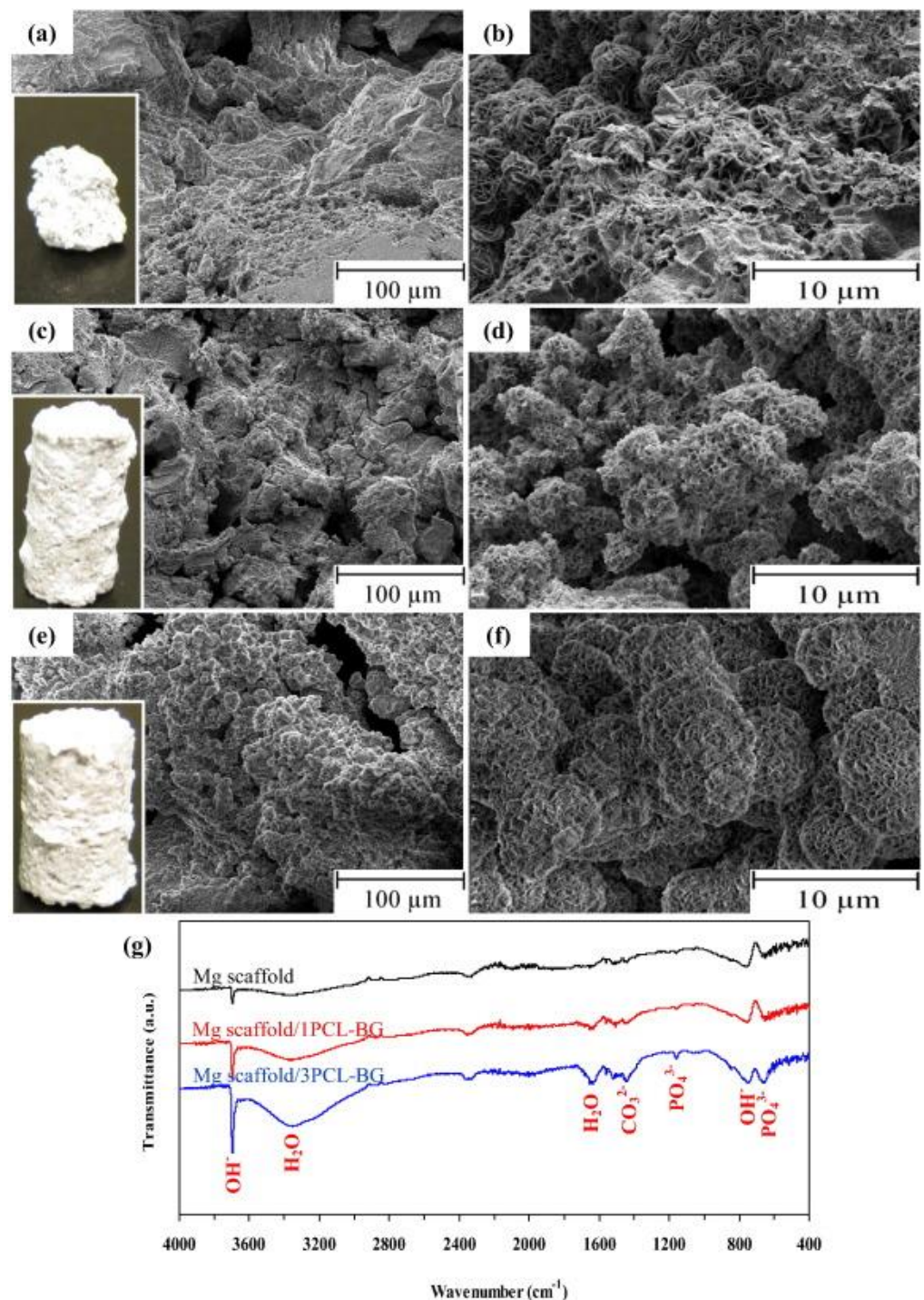

Fig. 4. SEM micrographs and photographs of uncoated $M g$ scaffold $(a, b), M g$ scaffold/1PCL-BG (c, d), and Mg scaffold/3PCL-BG (e, f) samples after $48 \mathrm{~h}$ immersion in the SBF, and FTIR spectrum of the precipitated white layers in cauliflower-like structure on the surface of samples after $48 \mathrm{~h}$ immersion in the SBF $(\mathrm{g})$. 
NOT THE PUBLISHED VERSION; this is the author's final, peer-reviewed manuscript. The published version may be accessed by following the link in the citation at the bottom of the page.

\subsection{In vitro biodegradation}

Fig. 5 shows the changes in weight gain (a), weight loss (b) and $\mathrm{pH}$ value (c) versus immersion time for $\mathrm{Mg}$ scaffold, $\mathrm{Mg}$ scaffold/1PCLBG, and Mg scaffold/3PCL-BG immersed in the SBF. These graphs present a comparison of samples' degradation behavior. Depending on the corrosion mechanism of metal/alloys in physiological environment, degradation reaction could lead to the weight loss of $\mathrm{Mg}$ substrates and $\mathrm{pH}$ variation of the immersion medium. ${ }^{22}$ Formation of degradation products on the surface during the immersion test can increase the weight of the scaffolds. However, samples may also lose their original contents due to the actual degradation. At this stage of the experiment, the combination of these two procedures is called "scaffold weight gain" which is demonstrated in Fig. 5a. A comparison between the uncoated and coated $\mathrm{Mg}$ scaffold images in Fig. 1 and the insets in Fig. 4 shows that a white layer has been covered on the surface of samples. Thus, based on the images in Fig. 1 and Fig. 4 as well as the amounts of weight gain of samples in Fig. 5a, it can be concluded that a degradation product layer has been formed on the surface during the SBF incubation. It can be seen from this Fig. that about $-100 \%, 56.1 \%$, and $59.7 \%$ weight gain is observed after $144 \mathrm{~h}$ immersion for $\mathrm{Mg}$ scaffold, Mg scaffold/1PCL-BG, and Mg scaffold/3PCL-BG, respectively. According to Fig. 5a, PCL-BG coating on the $\mathrm{Mg}$ scaffolds has an influence on their weight gain. The uncoated $\mathrm{Mg}$ scaffold degraded completely after $96 \mathrm{~h}$ immersion time $(-100 \%)$. At the next step, the degradation products were cleaned from the samples and scaffold weight was measured and compared with their original weight before immersion test, which can be called scaffold weight loss. Clearly, both uncoated and coated Mg scaffolds degraded with time, and the weight loss of the uncoated Mg scaffold was significantly higher than those of the coated $\mathrm{Mg}$ scaffolds. Furthermore, as for coated $\mathrm{Mg}$ scaffolds, the weight loss of $\mathrm{Mg}$ scaffold/1PCL-BG was higher than Mg scaffold/3PCL-BG. According to Fig. 4b, after $144 \mathrm{~h}$, the weight loss of $\mathrm{Mg}$ scaffold, $\mathrm{Mg}$ scaffold/1PCLBG, and Mg scaffold/3PCL-BG was about $100 \%, 42.72 \%$ and $12.4 \%$, respectively and the uncoated $\mathrm{Mg}$ scaffold was completely degraded after $96 \mathrm{~h}$. The $\mathrm{pH}$ of SBF was measured during the immersion of the samples. According to Fig. 5c, the $\mathrm{pH}$ of the SBF went up rapidly during the first hours of exposure, and then remained at a steady

Materials Science and Engineering: C, Vol 49 (April 2015): pg. 436-444. DOI. This article is @ Elsevier and permission has been granted for this version to appear in e-Publications@Marquette. Elsevier does not grant permission for this article to be further copied/distributed or hosted elsewhere without the express permission from Elsevier. 
value. However, the $\mathrm{pH}$ change for the uncoated $\mathrm{Mg}$ scaffold was higher than the coated ones and the increase in $\mathrm{pH}$ value was the lowest for Mg scaffold/3PCL-BG. After $48 \mathrm{~h}$ immersion in the SBF, the $\mathrm{pH}$ value of $\mathrm{Mg}$ scaffold, $\mathrm{Mg}$ scaffold/1PCL-BG, and Mg scaffold/3PCLBG reached 7.4 to $9.55,8.65$, and 8.37 , respectively. Since the uncoated $\mathrm{Mg}$ scaffold was degraded entirely after $48 \mathrm{~h}$, there was not any relative data for its $\mathrm{pH}$ data. Regarding the results of weight gain, weight loss, and $\mathrm{pH}$ measurement, significant differences between each two samples in pairs of Mg scaffold \& Mg scaffold/1PCL-BG, Mg scaffold \& Mg scaffold/3PCL-BG and Mg scaffold/1PCL-BG \& Mg scaffold/3PCL-BG were observed, which are exhibited by the asterisks symbol $(* p<0.05)$ on top of the columns in Fig. 5. According to the results of statistical surveys, the amounts of weight gain, weight loss, and $\mathrm{pH}$ values for both of the $\mathrm{Mg}$ scaffold/1PCL-BG and $\mathrm{Mg}$ scaffold/3PCL-BG samples were significantly different from those of the Mg scaffold sample, indicating that the coating has substantially influenced the degradation of $\mathrm{Mg}$ scaffold sample. Moreover, $\mathrm{Mg}$ scaffold/1PCL-BG is significantly different from Mg scaffold/3PCL-BG in terms of weight gain, weight loss, and $\mathrm{pH}$ values indicating that the number of coating layer is a key factor on the degradation behavior of samples.
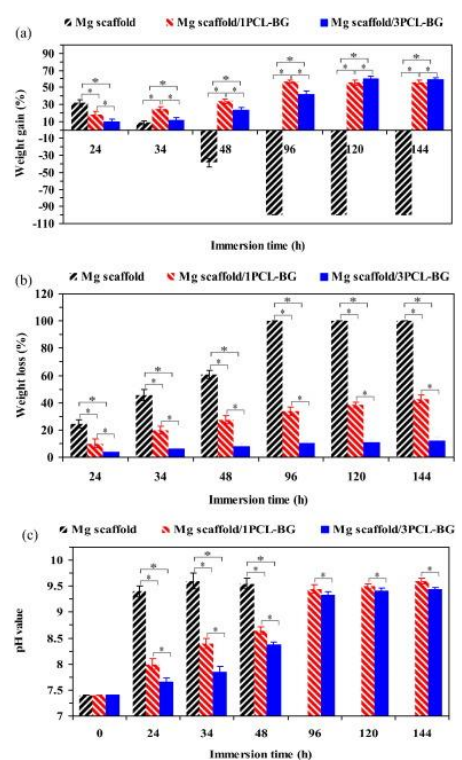

Fig. 5. The changes in weight gain (a), weight loss (b) and $\mathrm{pH}$ value (c) versus immersion time for Mg scaffold, Mg scaffold/1PCL-BG, and Mg scaffold/3PCL-BG immersed in the SBF. Statistically significant alterations between the couples of $\mathrm{Mg}$ scaffold \& Mg scaffold/1PCL-BG, Mg scaffold/1PCL-BG \& Mg scaffold/3PCL-BG, and Mg scaffold $\&$ Mg scaffold/3PCL-BG samples are shown by asterisks $(* p<0.05)$.

Materials Science and Engineering: C, Vol 49 (April 2015): pg. 436-444. DOI. This article is (C) Elsevier and permission has been granted for this version to appear in e-Publications@Marquette. Elsevier does not grant permission for this article to be further copied/distributed or hosted elsewhere without the express permission from Elsevier. 
Generally, the degradation of Mg alloys is known to be high in the first hours of exposure to the physiological media. This is mainly due to the fact that the corrosion protective layer needs more time for formation. ${ }^{45}$ Therefore, we particularly investigated the first hours of degradation and its effect on the stability of the Mg scaffolds. The degradation of $\mathrm{Mg}$ in biofluids is described by the following reactions: 13,16

equation(1)

$\mathrm{Mg}(\mathrm{s})+2 \mathrm{H}_{2} \mathrm{O} \rightarrow \mathrm{Mg}(\mathrm{OH})_{2(\mathrm{~s})}+\mathrm{H}_{2}(\mathrm{~g}) ;$

equation(2)

$\mathrm{Mg}(\mathrm{s})+2 \mathrm{Cl}^{-} \rightarrow \mathrm{MgCl}_{2}$

$\operatorname{Mg}(\mathrm{OH})_{2(\mathrm{~s})}+2 \mathrm{Cl}^{-}{ }_{(\mathrm{aq})} \rightarrow \mathrm{MgCl}_{2}+2 \mathrm{OH}^{-}{ }_{(\mathrm{aq})}$.

equation(3)

Degradation is accompanied by an alkalization of the corrosive media due to the production of hydroxide ions $\left(\mathrm{OH}^{-}\right)$. The high proportion of hydroxide ions supports the formation of magnesium hydroxide (reaction 1), which in turn acts as a protective layer against corrosion. Magnesium hydroxide is disrupted by chloride ions with the release of $\mathrm{OH}^{-}$(reactions (2) and (3)) ${ }^{30,46}$

The $\mathrm{Mg}(\mathrm{OH})_{2}$ film and the precipitation of ions on the surface cause the weight gain of the scaffolds. Although $\mathrm{Mg}(\mathrm{OH})_{2}$ is slightly soluble in SBF, rigorous degradation occurred in aqueous physiological media, as $\mathrm{Mg}(\mathrm{OH})_{2}$ reacts with $\mathrm{Cl}^{-}$to form highly soluble magnesium chloride $\left(\mathrm{MgCl}_{2}\right)$ and hydrogen bubbles (reaction 3). ${ }^{24}$ An accelerated $\mathrm{pH}$ increase during the first hours of immersion has been reported by several in vitro studies. ${ }^{22,30}$ When the reactions among all the ions obtain equilibrium, the $\mathrm{pH}$ values of the solutions will reach a stable value. The decelerated increase of $\mathrm{pH}$ may be correlated to the deposition of magnesium hydroxide and other phosphate- and calcium containing compositions, which formed on the surface of the $\mathrm{Mg}$ samples. ${ }^{22}$ Interestingly, the $\mathrm{pH}$ of the SBF increased more with the immersion of uncoated $\mathrm{Mg}$ scaffolds than coated $\mathrm{Mg}$ scaffolds. This finding demonstrated the more progressed and faster degradation of

Materials Science and Engineering: C, Vol 49 (April 2015): pg. 436-444. DOI. This article is @ Elsevier and permission has been granted for this version to appear in e-Publications@Marquette. Elsevier does not grant permission for this article to be further copied/distributed or hosted elsewhere without the express permission from Elsevier. 
the uncoated $\mathrm{Mg}$ scaffolds. These interpretations were supported by the determined weight loss for both uncoated and coated $\mathrm{Mg}$ scaffolds.

The PCL-BG coating acted as a barrier layer on the surface to avoid fast degradation of scaffolds. Hydrogen bubbles may play the role of removing the degradation products formed on the surface leading to lower weight gain for the coated scaffolds in initial times of immersion. According to the SEM and FTIR analyses in Fig. 4, the degradation products are mainly composed of magnesium hydroxide and calcium phosphate products. Although, these products are degraded themselves by time, they can operate as a corrosion protective layer for $\mathrm{Mg}$ scaffold substrate as the uncoated $\mathrm{Mg}$ scaffold substrate has a rapid degradation in the SBF due to the presence of $\mathrm{Cl}$ ions. Thus, formation of a layer on the surface can protect it from the exposure to the solution. Previous investigations have studied this fact more explicitly. 47,48

SEM micrographs of Mg scaffold ( $a, b), M g$ scaffold/1PCL-BG (c, d) and $\mathrm{Mg}$ scaffold/3PCL-BG $(e, f)$ after $48 \mathrm{~h}$ immersion in the SBF have been presented in Fig. 6 . These images present the difference of the degradation morphology of samples after removing the degradation products. From Fig. $6 a$, b, it can be seen that cleavage cracking has appeared on the surface of $\mathrm{Mg}$ grains, and it is assumed the crack propagation occurred in the process of degradation. In contrast, it could be clearly observed that the Mg scaffold/1PCL-BG (Fig. 6c, d) and Mg scaffold/3PCL-BG (Fig. 6e, f) samples were subjected to a more mild and uniform degradation attack compared to the uncoated $\mathrm{Mg}$ scaffold. The coated scaffold maintained shape steadiness with the presence of little pits on the surface and only a few degradation-attacked spots were present on the as-cleaned $\mathrm{Mg}$ scaffold/1PCL-BG and Mg scaffold/3PCL-BG samples; and the depth of degradation pits was much shallower than that of the substrate. In other words, the remaining area of the sample with the $\mathrm{Mg}$ scaffold/1PCL-BG and Mg scaffold/3PCL-BG was much larger than that of the Mg scaffold. Moreover, the amount of microcracks that formed on the surface of $\mathrm{Mg}$ grains coated $\mathrm{Mg}$ scaffolds was less than on the uncoated Mg scaffold. This may be mainly due to the PCL-BG coating acting as a barrier layer. On the other hand, the decreased degradation rate reveals that the $\mathrm{Mg}$ scaffold/1PCL-BG and $\mathrm{Mg}$ scaffold/3PCL-BG could efficiently protect the substrate from the

Materials Science and Engineering: C, Vol 49 (April 2015): pg. 436-444. DOI. This article is @ Elsevier and permission has been granted for this version to appear in e-Publications@Marquette. Elsevier does not grant permission for this article to be further copied/distributed or hosted elsewhere without the express permission from Elsevier. 
NOT THE PUBLISHED VERSION; this is the author's final, peer-reviewed manuscript. The published version may be accessed by following the link in the citation at the bottom of the page.

degradation attacks and it might be stated that the anti-corrosion performance of $\mathrm{Mg}$ alloy with $\mathrm{Mg}$ scaffold/1PCL-BG and $\mathrm{Mg}$ scaffold/3PCL-BG is enhanced as compared with the bare $\mathrm{Mg}$.
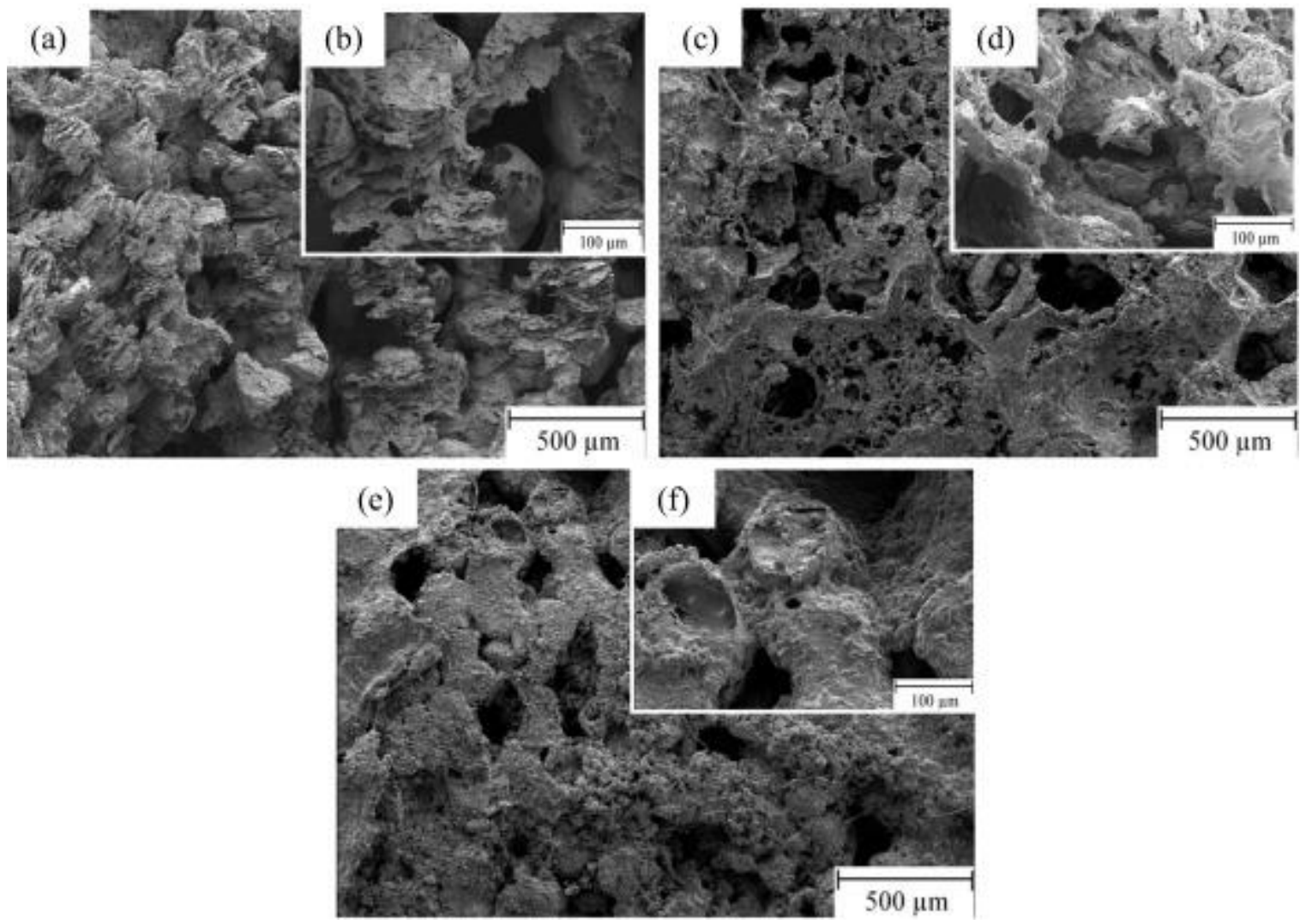

Fig. 6. SEM micrographs of $M g$ scaffold (a, b), Mg scaffold/1PCL-BG (c, d) and Mg scaffold/3PCL-BG $(e, f)$ after $48 \mathrm{~h}$ immersion in the SBF.

\subsection{Mechanical stability}

The compressive stress-strain curves of the Mg scaffold, $\mathrm{Mg}$ scaffold/1PCL-BG, and Mg scaffold/3PCL-BG during immersion of the samples for $24 \mathrm{~h} \mathrm{(a),48} \mathrm{h} \mathrm{(b),} \mathrm{and} 144 \mathrm{~h} \mathrm{(c)} \mathrm{in} \mathrm{the} \mathrm{SBF} \mathrm{are} \mathrm{presented}$ in Fig. 7 and the values of compressive strength of samples versus immersion time are presented in Fig. 8. The compressive strength data of all of the groups before the immersion were similar, equal to $52 \mathrm{MPa}$. Afterward the compressive strength of both uncoated and coated groups declined over the immersion time, but the strength of the coated group remained higher than that of the uncoated one and indicated a much more modest decline trend. What is evident in the figures is that the values of the compressive strength for the $\mathrm{Mg}$ 
NOT THE PUBLISHED VERSION; this is the author's final, peer-reviewed manuscript. The published version may be accessed by following the link in the citation at the bottom of the page.

scaffold/3PCL-BG are highest and uncoated Mg scaffolds are lowest compared to the other samples and Mg scaffold/1PCL-BG is between those. It can be seen that the compressive stress of the Mg scaffolds increases with the presence of PCL-BG coating and increase in the coating layers. Specifically, by increasing the coating layers of PCL-BG as indicated by $\mathrm{Mg}$ scaffold/1PCL-BG and Mg scaffold/3PCL-BG, the compressive strength of the immersed $\mathrm{Mg}$ scaffold went up markedly from $10 \mathrm{MPa}$ to $17 \mathrm{MPa}$, respectively after $144 \mathrm{~h}$ immersion. The significant variations between each two samples regarding the obtained results of compressive strength versus immersion time have been indicated by asterisks on the columns $(* p<0.05)$ in Fig. 8 .

Statistical analysis of the compressive strength data revealed that the compressive strength of $\mathrm{Mg}$ scaffold/1PCL-BG and Mg scaffold/3PCLBG samples was considerably different from that of the Mg scaffold sample. The Mg scaffold/3PCL-BG sample was also noticeably different from the Mg scaffold/1PCL-BG sample in terms of compressive strength. Overall, Fig. 8 indicated a substantial improvement in the compressive strength of $\mathrm{Mg}$ scaffold with PCL-BG coating in comparison with the uncoated $\mathrm{Mg}$ scaffold.

Materials Science and Engineering: C, Vol 49 (April 2015): pg. 436-444. DOI. This article is @ Elsevier and permission has been granted for this version to appear in e-Publications@Marquette. Elsevier does not grant permission for this article to be further copied/distributed or hosted elsewhere without the express permission from Elsevier. 
NOT THE PUBLISHED VERSION; this is the author's final, peer-reviewed manuscript. The published version may be accessed by following the link in the citation at the bottom of the page.
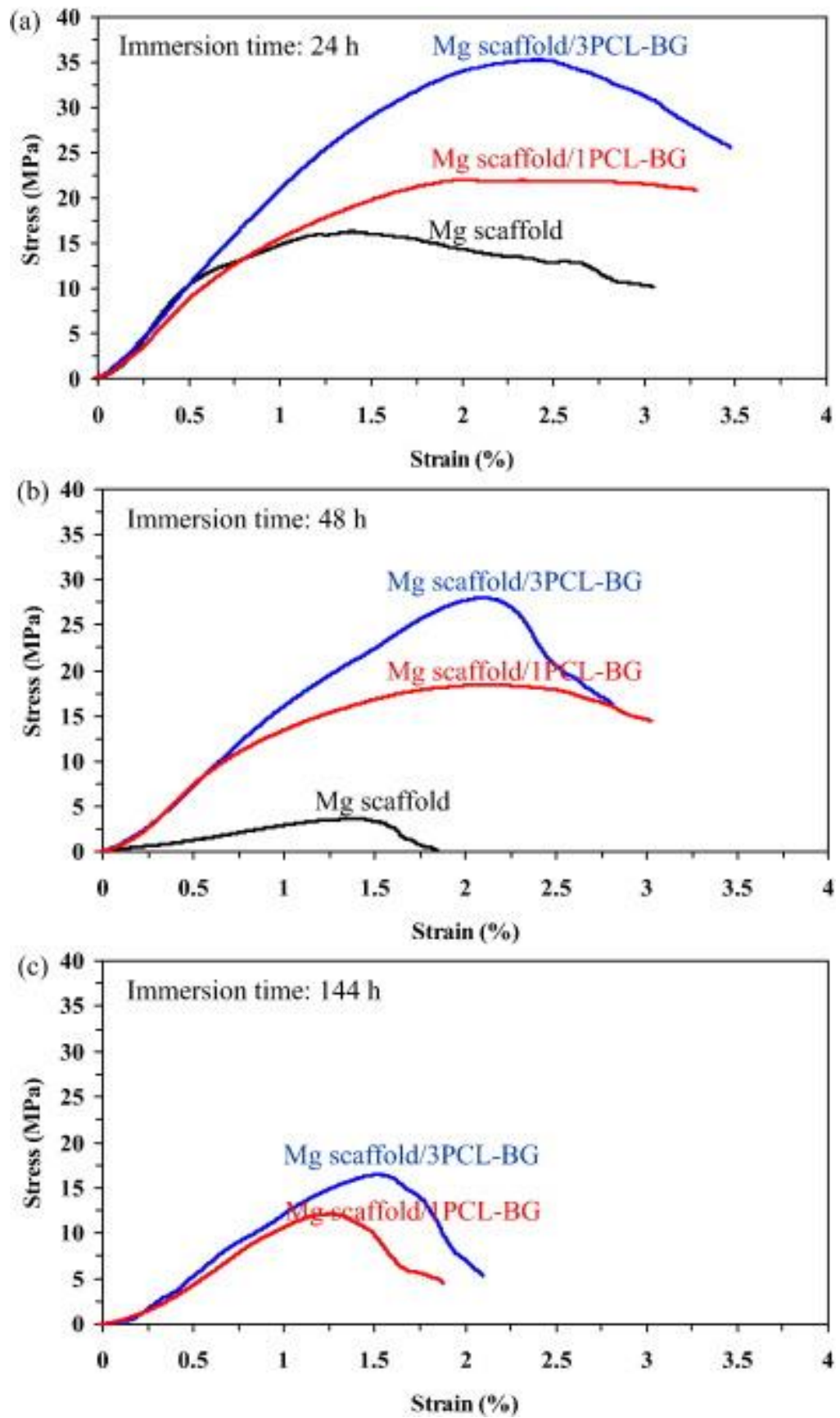

Fig. 7. The compressive stress-strain curves of the $\mathrm{Mg}$ scaffold, $\mathrm{Mg}$ scaffold/1PCL-BG, and $\mathrm{Mg}$ scaffold/3PCL-BG during immersion of the samples for $24 \mathrm{~h}(\mathrm{a}), 48 \mathrm{~h}$ (b), and $144 \mathrm{~h}(\mathrm{c})$ in the SBF. 


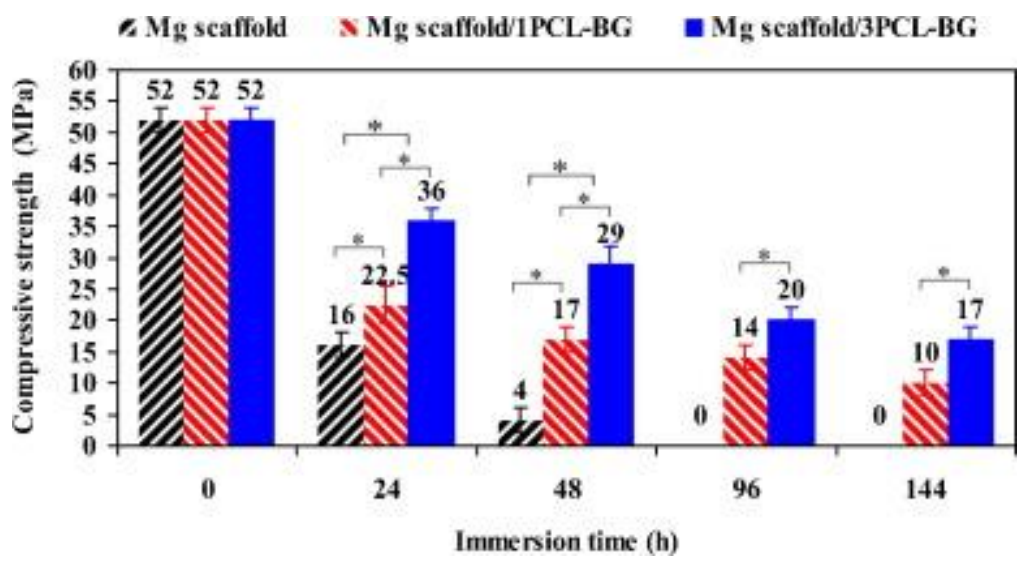

Fig. 8. The compressive strength of $M g$ scaffold, $M g$ scaffold/1PCL-BG, and $M g$ scaffold/3PCL-BG versus immersion time in the SBF. Statistically significant differences between each two groups are demonstrated by asterisks $(* p<0.05)$.

Therefore, since PCL-BG can improve the degradation resistance of $\mathrm{Mg}$ scaffolds, it increased the mechanical integrity of samples during immersion in the SBF. Note that the uncoated Mg scaffold was degraded completely after $48 \mathrm{~h}$, so there was not any data relative to this time and after that. Additionally, the compressive strength of the uncoated Mg scaffolds, Mg scaffold/1PCL-BG and Mg scaffold/3PCL-BG decreased with time. Though, a large decrease of compressive strength is seen after $24 \mathrm{~h}$ of immersion for the uncoated $\mathrm{Mg}$ scaffold.

Therefore, the PCL-BG coating protected the Mg scaffold from rapid degradation and maintained the mechanical strength more at the initial immersion period.

This may be due to the severe local degradation of the uncoated Mg scaffold as can be seen in Fig. 6. Similarly, Zhang et al. ${ }^{49}$ have reported a rapid decrease of bending strength of $\mathrm{Mg}$ alloy in the early degradation stage. Thus, its relative lower degradation rate and degradation structure may be a reason for the slower decrease of strength for Mg scaffolds.

Thus, the results of this test indicate that the mechanical integrity of $\mathrm{Mg}$ scaffolds improved by employing the PCL-BG coating, because Mg scaffold with PCL-BG coating may not be as sensitive to the surface defects as uncoated Mg scaffold. 


\section{Conclusion}

$\mathrm{Mg}$ and its alloys have been broadly studied for biomedical applications due to their biodegradable and mechanical properties. However, the fast degradation rate of $\mathrm{Mg}$ has restricted its applications especially as bone tissue engineering scaffolds. In the present research, a powder metallurgy technique was used to produce $\mathrm{Mg}$ scaffolds following by coating them with polycaprolactone (PCL) and bioactive glass (BG). The structural characteristics, degradation, bioactivity and mechanical behavior of the uncoated $\mathrm{Mg}$ scaffolds, $\mathrm{Mg}$ scaffold coated by 1 PCL-BG and 3PCL-BG during the immersion in simulated body fluid (SBF) were investigated. Experimental results demonstrate that the Mg scaffolds with PCL-BG coatings have noticeably enhanced degradation resistance, bioactivity and mechanical stability compared to the uncoated $\mathrm{Mg}$ scaffolds. Therefore, the porous Mg scaffold with PCL-Mg coating has the potential to serve as a suitable degradable metallic scaffold for hard tissue regeneration.

\section{Acknowledgments}

The work was partially supported by OCAST (Grant no. AR131-054 8161), AFOSR (Grant no. FA9550-10-1-0010) and NSF (Grant no. 0933763).

\section{References}

${ }^{1}$ K.F. Farraro, K.E. Kim, S.L. Woo, J.R. Flowers, M.B. McCullough. J. Biomech., 47 (2013), pp. 1979-1986

2 K. Alvarez, H. Nakajima. Materials, 2 (2009), pp. 790-832

${ }^{3}$ E. Salahinejad, M.J. Hadianfard, D.D. Macdonald, S. Sharifi-Asl, M. Mozafari, K.J. Walker, A.T. Rad, S.V. Madihally, L. Tayebi. PLoS ONE, 8 (2013), p. e61633

${ }^{4}$ M. Yazdimamaghani, D. Vashaee, S. Assefa, K.J. Walker, S.V. Madihally, G.A. Köhler, L. Tayebi. J. Biomed. Nanotechnol., 10 (2014), pp. 911931

5 M. Mozafari, E. Salahinejad, V. Shabafrooz, M. Yazdimamaghani, D. Vashaee, L. Tayebi. Int. J. Nanomedicine, 8 (2013), p. 1665

${ }^{6}$ H. Hornberger, S. Virtanen, A. Boccaccini. Acta Biomater., 8 (2012), pp. 2442-2455

7 M. Razavi, M. Fathi, O. Savabi, B.H. Beni, D. Vashaee, L. Tayebi. Colloids Surf. B: Biointerfaces, 117 (2014), pp. 432-440

Materials Science and Engineering: C, Vol 49 (April 2015): pg. 436-444. DOI. This article is @ Elsevier and permission has been granted for this version to appear in e-Publications@Marquette. Elsevier does not grant permission for this article to be further copied/distributed or hosted elsewhere without the express permission from Elsevier. 
NOT THE PUBLISHED VERSION; this is the author's final, peer-reviewed manuscript. The published version may be accessed by following the link in the citation at the bottom of the page.

8 M. Razavi, M. Fathi, O. Savabi, B. Hashemi Beni, D. Vashaee, L. Tayebi. Ceram. Int., 40 (2014), pp. 9473-9484

9 M. Yazdimamaghani, M. Razavi, D. Vashaee, L. Tayebi. Surf. Eng., 30 (2014), pp. 920-926

10 M. Razavi, M. Fathi, O. Savabi, S. Mohammad Razavi, B. Hashemi Beni, D. Vashaee, L. Tayebi. Mater. Lett., 113 (2013), pp. 174-178

11 M. Razavi, M. Fathi, O. Savabi, D. Vashaee, L. Tayebi. Phys. Sci. Int. J., 4 (2014), pp. 708-722

12 M.P. Staiger, A.M. Pietak, J. Huadmai, G. Dias. Biomaterials, 27 (2006), pp. 1728-1734

13 M. Razavi, M. Fathi, O. Savabi, B.H. Beni, S.M. Razavi, D. Vashaee, L. Tayebi. Appl. Surf. Sci., 288 (2014), pp. 130-137

14 J. Li, P. Han, W. Ji, Y. Song, S. Zhang, Y. Chen, C. Zhao, F. Zhang, X. Zhang, Y. Jiang. Mater. Sci. Eng. B, 176 (2011), pp. 1785-1788

15 M. Razavi, M. Fathi, O. Savabi, D. Vashaee, L. Tayebi. Surf. Interface Anal., 46 (2014), pp. 387-392

16 M. Razavi, M. Fathi, O. Savabi, M. Boroni. Res. Rev. Mater. Sci. Chem., 1 (2012), pp. 15-58

17 H. Zhuang, Y. Han, A. Feng. Mater. Sci. Eng. C, 28 (2008), pp. 1462-1466

${ }^{18}$ A. Tahmasbi Rad, N. Ali, H.S.R. Kotturi, M. Yazdimamaghani, J. Smay, D. Vashaee, L. Tayebi. J. Biomed. Mater. Res. A, 102 (2014), pp. 41694181

19 V. Shabafrooz, M. Mozafari, G.A. Köhler, S. Assefa, D. Vashaee, L. Tayebi. J. Biomed. Mater. Res. A, 102 (2014), pp. 3130-3139

20 M. Mozafari, M. Mehraien, D. Vashaee, L. Tayebi. Nanocomposites-New Trends and Developments, Publisher: InTech, (2012) http://dx.doi.org/10.5772/51058 ISBN 978-953-51-0762-0

${ }^{21}$ C. Wen, Y. Yamada, K. Shimojima, Y. Chino, H. Hosokawa, M. Mabuchi. Mater. Lett., 58 (2004), pp. 357-360

22 X. Gu, W. Zhou, Y. Zheng, Y. Liu, Y. Li. Mater. Lett., 64 (2010), pp. 18711874

${ }^{23}$ F. Witte, H. Ulrich, M. Rudert, E. Willbold. J. Biomed. Mater. Res. A, 81 (2007), pp. 748-756

24 G. Song. Corros. Sci., 49 (2007), pp. 1696-1701

25 N. Kirkland, J. Lespagnol, N. Birbilis, M. Staiger. Corros. Sci., 52 (2010), pp. 287-291

${ }^{26}$ E. Salahinejad, M. Hadianfard, D. Macdonald, M. Mozafari, D. Vashaee, L. Tayebi. Mater. Lett., 97 (2013), pp. 162-165

27 E. Salahinejad, M.J. Hadianfard, D.D. Macdonald, S. Sharifi, M. Mozafari, K.J. Walker, A.T. Rad, S.V. Madihally, D. Vashaee, L. Tayebi. J. Biomed. Nanotechnol., 9 (2013), pp. 1327-1335

28 J. Yang, F. Cui, I.S. Lee. Ann. Biomed. Eng., 39 (2011), pp. 1857-1871

Materials Science and Engineering: C, Vol 49 (April 2015): pg. 436-444. DOI. This article is @ Elsevier and permission has been granted for this version to appear in e-Publications@Marquette. Elsevier does not grant permission for this article to be further copied/distributed or hosted elsewhere without the express permission from Elsevier. 
NOT THE PUBLISHED VERSION; this is the author's final, peer-reviewed manuscript. The published version may be accessed by following the link in the citation at the bottom of the page.

${ }^{29}$ H. Kweon, M.K. Yoo, I.K. Park, T.H. Kim, H.C. Lee, H.-S. Lee, J.-S. Oh, T. Akaike, C.-S. Cho. Biomaterials, 24 (2003), pp. 801-808

30 H.M. Wong, K.W. Yeung, K.O. Lam, V. Tam, P.K. Chu, K.D. Luk, K. Cheung. Biomaterials, 31 (2010), pp. 2084-2096

31 G. Pitt, M. Gratzl, G. Kimmel, J. Surles, A. Sohindler. Biomaterials, 2 (1981), pp. 215-220

32 C.G. Pitt, F. Chasalow, Y. Hibionada, D. Klimas, A. Schindler. J. Appl. Polym. Sci., 26 (1981), pp. 3779-3787

33 M. Yazdimamaghani, T. Pourvala, E. Motamedi, B. Fathi, D. Vashaee, L. Tayebi. Materials, 6 (2013), pp. 3727-3741

34 M.Y. Mamaghani, M. Pishvaei, B. Kaffashi. Macromol. Res., 19 (2011), pp. 243-249

35 L.L. Hench, J. Wilson. An Introduction to Bioceramics. World Scientific (1993)

36 J.R. Jones, L.M. Ehrenfried, L.L. Hench. Biomaterials, 27 (2006), pp. 964973

37 T. Kokubo. Biomaterials, 12 (1991), pp. 155-163

${ }^{38}$ A. Shahini, M. Yazdimamaghani, K. Walker, M. Eastman, H. HatamiMarbini, B. Smith, J. Ricci, S. Madihally, D. Vashaee, L. Tayebi. Int. J. Nanomedicine, 9 (2014), pp. 167-181

39 M. Mozafari, F. Moztarzadeh, M. Tahriri. J. Non-Cryst. Solids, 356 (2010), pp. $1470-1478$

40 T. Kokubo, H. Takadama. Biomaterials, 27 (2006), pp. 2907-2915

${ }^{41}$ M. Shamsipur, N. Bahrami Adeh, M.S. Hajitarverdi, M. Yazdimamaghani, F. Zarei. Iran. J. Chem. Chem. Eng., 32 (2013)

42 J.R. Jones. Acta Biomater., 9 (2013), pp. 4457-4486

43 M. Razavi, M. Fathi, O. Savabi, D. Vashaee, L. Tayebi. J. Biomed. Mater. Res. A (2014) http://dx.doi.org/10.1002/jbm.a.35324

${ }^{44}$ M. Razavi, M. Fathi, O. Savabi, D. Vashaee, L. Tayebi. Ann. Biomed. Eng. (2014), pp. 1-14

45 G. Song, S. Song. Adv. Eng. Mater., 9 (2007), pp. 298-302

46 M. Yazdimamaghani, M. Razavi, D. Vashaee, L. Tayebi. Mater. Lett., 132 (2014), pp. 106-110

47 Y. Song, S. Zhang, J. Li, C. Zhao, X. Zhang. Acta Biomater., 6 (2010), pp. 1736-1742

48 M. Razavi, M. Fathi, O. Savabi, D. Vashaee, L. Tayebi. Mater. Sci. Eng. C, 41 (2014), pp. 168-177

${ }^{49}$ S. Zhang, X. Zhang, C. Zhao, J. Li, Y. Song, C. Xie, H. Tao, Y. Zhang, Y. He, Y. Jiang. Acta Biomater., 6 (2010), pp. 626-640

Corresponding author at: School of Materials Science and Engineering, Helmerich Advanced Technology Research Center, Oklahoma State University, Tulsa, OK 74106, USA.

Materials Science and Engineering: C, Vol 49 (April 2015): pg. 436-444. DOI. This article is @ Elsevier and permission has been granted for this version to appear in e-Publications@Marquette. Elsevier does not grant permission for this article to be further copied/distributed or hosted elsewhere without the express permission from Elsevier. 
NOT THE PUBLISHED VERSION; this is the author's final, peer-reviewed manuscript. The published version may be accessed by following the link in the citation at the bottom of the page.

${ }^{1}$ These authors contributed equally to this work.

Materials Science and Engineering: C, Vol 49 (April 2015): pg. 436-444. DOI. This article is @ Elsevier and permission has been granted for this version to appear in e-Publications@Marquette. Elsevier does not grant permission for this article to be further copied/distributed or hosted elsewhere without the express permission from Elsevier. 